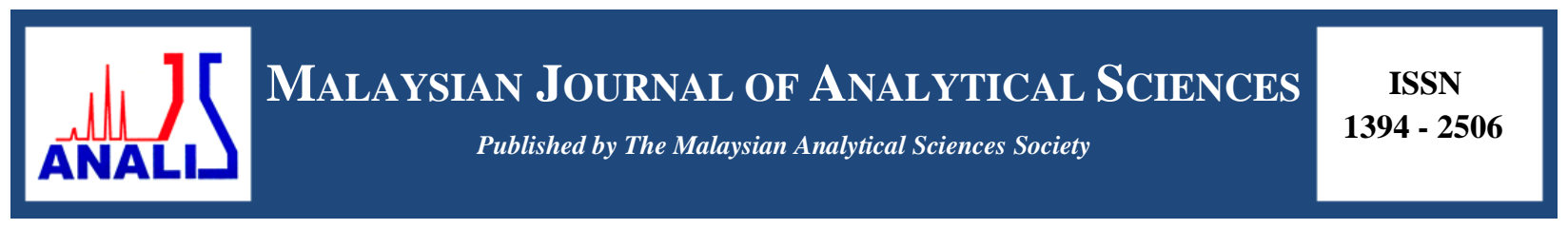

\title{
THE ASSESSMENT OF INDOOR RADON-222 CONCENTRATION AND EMANATION RATE AT GUA PENYU, PAHANG
}

\author{
(Penilaian Kepekatan dan Kadar Pancaran Dalaman Radon-222 di Gua Penyu, Pahang) \\ Junaidah Md Sani ${ }^{1}$, Nuramirah Alias ${ }^{1}$, Nazree Ahmad ${ }^{1}$, Ahmad Saat ${ }^{2}$ \\ ${ }^{l}$ Faculty of Applied Sciences, \\ Universiti Teknologi MARA Cawangan Pahang, 26400 Bandar Tun Abdul Razak Jengka, Pahang, Malaysia \\ ${ }^{2}$ Institute of Science, \\ Universiti Teknologi MARA, 40450 Shah Alam, Selangor, Malaysia \\ *Corresponding author: ajun@pahang.uitm.edu.my
}

Received: 4 December 2016; Accepted: 1 December 2017

\begin{abstract}
The indoor Radon-222 concentration and emanation rate in Gua Penyu, Gua Gelanggi Complex, Pahang were measured using Solid State Nuclear Track Detector CR-39 (SSNTD CR-39) to evaluate the air quality and radiological exposure in this recreational cave. A total of 20 SSNTD CR-39 dosimeters were placed inside the cave at about $15 \mathrm{~m}$ apart each. 10 dosimeters were embedded $5 \mathrm{~cm}$ into cave floor to determine emanation rate, while the other 10 dosimeters were placed at one meter above the floor level for concentration measurement. The control samples were placed outside the cave $15 \mathrm{~m}$ from the main entrance. These SSNTD CR-39 samples were left for a month before undergone etching process with $\mathrm{NaOH}$ solution $(6 \mathrm{M})$ at $70{ }^{\circ} \mathrm{C}$ for six hours. The radon concentration and emanation rate were both determined from the track density in each $\mathrm{CR}-39(1 \mathrm{~cm} \times 1 \mathrm{~cm})$

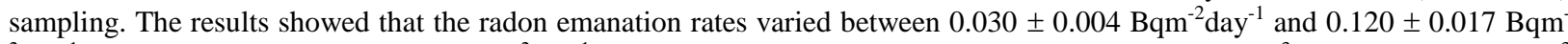
${ }^{2} \mathrm{day}^{-1}$ with the average rate of $0.080 \mathrm{Bqm}^{-2} \mathrm{day}^{-1}$. The radon concentration was between $3.72 \pm 1.60 \mathrm{Bqm}^{-3}$ and $_{7.89} \pm 2.10 \mathrm{Bqm}^{-3}$ with the average of $4.8 \mathrm{Bqm}^{-3}$. These values were lower compared to indoor concentration allowed by the International Commission on Radiation Protection (ICRP) 2009 that is $200-300 \quad \mathrm{Bqm}^{-3}$. The annual effective dose were found to range between $0.09 \mathrm{mSv} \cdot \mathrm{y}^{-1}$ and $0.20 \mathrm{mSv} \cdot \mathrm{y}^{-1}$ which was lower than recommended value 3 to $10 \mathrm{mSv} \cdot \mathrm{y}^{-1}$ put forth by the ICRP 1993 . Hence, this recreational cave is safe to be visited by public.
\end{abstract}

Keywords: limestone cave, emanation rate, indoor radon

\begin{abstract}
Abstrak
Kepekatan dan kadar pancaran dalaman Radon-222 dalam Gua Penyu, Kompleks Gua Gelanggi, Pahang telah diukur menggunakan Pengesan Jejak Nuklear Keadaan Pepejal CR-39 (SSNTD CR-39) untuk menilai kualiti udara dan pendedahan radiologi dalam gua rekreasi ini. Sejumlah 20 dosimeter SSNTD CR-39 telah ditempatkan dalam gua ini setiap satu berjarak kira-kira $15 \mathrm{~m} .10$ dosimeter telah dibenamkan $5 \mathrm{~cm}$ ke dalam lantai gua untuk penentuan kadar pancaran, manakala 10 dosimeter lain ditempatkan pada satu meter di atas aras lantai untuk pengukuran kepekatan. Sampel kawalan ditempatkan di luar gua $15 \mathrm{~m}$ hadapan pintu masuk utama. Sampel SSNTD CR-39 ini ditinggalkan selama sebulan sebelum melalui proses punaran dalam larutan $\mathrm{NaOH}(6 \mathrm{M})$ pada $70{ }^{\circ} \mathrm{C}$ selama enam jam. Kepekatan dan kadar pancaran radon keduanya ditentukan dari ketumpatan jejak dalam setiap sampel $(1 \mathrm{~cm} \times 1 \mathrm{~cm})$ CR-39. Hasil kajian menunjukkan bahawa kadar pancaran radon berada antara $0.030 \pm 0.004 \mathrm{Bqm}^{-2}$ hari $^{-1}$ dan $0.120 \pm 0.017 \mathrm{Bqm}^{-2}$ hari ${ }^{-1}$ dengan purata $0.080 \mathrm{Bqm}^{-2}$ hari $^{-1}$. Kepekatan radon antara $3.72 \pm$ $1.60 \mathrm{Bqm}^{-3}$ and $7.89 \pm 2.10 \mathrm{Bqm}^{-3}$ dengan purata $4.8 \mathrm{Bqm}^{-3}$. Nilai-nilai ini lebih rendah berbanding nilai dalaman $200-300$ $\mathrm{Bqm}^{-3}$ yang dibenarkan oleh Jawatankuasa Perlindungan Radiasi Antarabangsa (ICRP) 2009. Didapati dos berkesan tahunan berada antara $0.09 \mathrm{mSv}_{\text {.tahun }}{ }^{-1}$ dan $0.20 \mathrm{mSv}^{-1 a h u \mathrm{n}^{-1}}$ lebih rendah berbanding dengan nilai tahunan yang disyorkan oleh ICRP 1993 iaitu 3 hingga 10 mSv.tahun ${ }^{-1}$. Justeru, gua rekreasi ini adalah selamat dikunjungi oleh orang awam.
\end{abstract}


Kata kunci: gua batu kapur, kadar pancaran, radon dalaman

\section{Introduction}

Uranium-238 is a radionuclide which undergoes spontaneous decay chain through Radium-226 which then decays into Radon-222. This naturally occurring gas could be found everywhere on earth especially in rocky and mountainous areas such as mines and caves as well as soil and water. Radon is a radioactive gas that is colorless, odorless and tasteless. Being the heaviest noble gas, it is chemically inert and easily mobilizes in long distances through soil and rocks [1]. In addition, radon is a single atom gas. Thus, it can easily penetrate through fissures and cracks. The half-life of Radon-222 is 3.8 days makes it the most potential source of radiological exposure to the general public [2]. Radon gas from the soils escapes to the atmosphere through diffusion, evaporation of soil moisture and exhalation due to temperature or pressure changes. The gas suspends in the air which we breathe in. The fact that it is much denser than air makes it effortlessly inhaled by cave tourist. However, when radon is diluted to extremely low concentrations outdoor, the risk is very low. Nonetheless, radon content in indoor atmosphere typically contributes up to 50\% to the background radiations [3]. Radon is a radiological poison associated with carcinogenic effect to human being [4]. In closed environment such as caves, mines and poor ventilated house, the inhalation of accumulated radon poses significant health hazards to human being [5]. International Atomic Energy Agency [6] and $\mathrm{Yu}$ et al. [7] reported that radon gas was the cause of lung cancer especially among underground miners. Furthermore, the ionizing alpha particles emitted by radon progenies (Polonium-218 and Polonium-214) may also lead to DNA damages in the respiratory system. According to the World Health Organization [8] which is also supported by Oufni et al. [9], the most notably health effect of radon is lung cancer. Likewise, the U.S Environmental Protection Agency in 1992, also reported an estimated 14,000 deaths per year due to Radon-222.

Caves are one of sought-after tourist recreational enthusiasm in Malaysia as well as interesting excavation sites for archeologist. The Gua Kota Gelanggi, which was chosen for radiological assessment, is a limestone cave located in Pahang state, Malaysia. It consists of a number of caves such as Gua Terang Bulan, Gua Bersanding, Gua Tongkat, Gua Balai, Gua Gajah, Gua Penyu, Gua Angin, Gua Tanggal 99, Gua Hijau and Gua Kelawat, which are open to public for cave exploration, rock climbing, abseiling, camping, jungle tracking and hiking. Visitors are ignorance about the existence of radon in the cave atmosphere and its radiological risk. Malaysia's tropical and humid nature provides the best trail for the migration of radon gas in caves which are greatly influenced by temperature difference, humidity, and rocks. The Gua Penyu cave that was chosen as a study site has no other opening except the main entrance. Consequently, there is a possibility for the radon gas to be enriched significantly due to the limited ventilation. Besides, this cave is frequented by the local visitors and tourist who is guest of the Tekam Plantation Resort. According to Koltai et al. [10], the radon concentration of caves air around the world ranges from 0.1 to $20 \mathrm{kBq} \mathrm{m}^{-3}$. Thus, by assessing the indoor radon concentration and emanation rate in this recreational cave, information regarding the air quality and amount of radiological exposure can be used to develop certain precautions that could be adopted by its visitors.

The objective of this study is to measure the indoor Radon-222 concentrations and emanation rates in Gua Penyu cave using the Alpha Track Detector (ATD). ATD was chosen because it is a simple and efficient method for sampling period from one to 12 months. Moreover, it provides reliable data and inexpensive compared to the other detectors [1, 8]. The dosimeter that was used in this study is Solid State Nuclear Track Detector (SSNTD) CR-39 which is very sensitive to the alpha particles that strike its surface [11]. These alpha particles would strike the dielectric detector and produce a damage area that was called latent track. The latent track underwent etching process afterwards to be enlarged sufficiently making it visible under the optical microscope. The number of tracks is proportional to the concentration of radon and the period of exposure.

\section{Preparation of dosimeters}

\section{Materials and Methods}

The radon level measurements were performed using Solid State Nuclear Track Detector (SSNTD) CR-39 manufactured by Tastrak UK. The CR-39 track detector sheets were cut to $1 \mathrm{~cm} \times 1 \mathrm{~cm}$ dimension. The CR-39 as the dosimeter was exposed to radon according to the can-mode configuration [12]. Each dosimeter was made of a 
transparent polymer cup $6.7 \mathrm{~cm}$ in diameter and $4 \mathrm{~cm}$ in height. The lid of the cup was pierced in the centre to make a circular hole of $1 \mathrm{~cm}$ diameter. This hole was then sealed by mean of a domestic soft sponge $5 \mathrm{~mm}$ thick. The sponge would act as a filter that limited access to moisture as well as to block the entry of radon progeny daughters and to prevent contamination from impurities in the atmosphere. As a result, only the alpha particles emanated from radon would diffuse into the cup and strike the detector [13]. Another CR-39 sheet was attached to the inner bottom of the cup using a double sided tape. The tape helped to keep the CR-39 immobile so as to reduce error that might be caused by movement. The design of the dosimeter is shown in Figure 1.
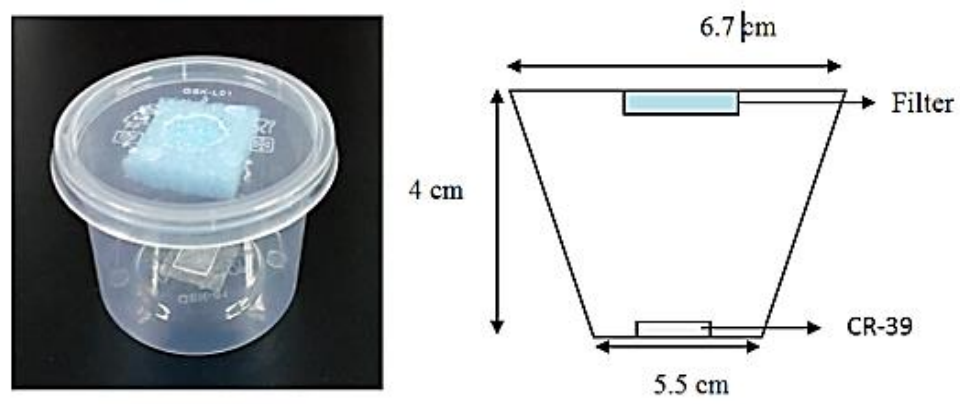

Figure 1. The schematic dosimeter for radon monitoring device

\section{The sampling method}

A total of 20 dosimeters which was $15 \mathrm{~m}$ apart from each other were placed inside the Gua Penyu cave. 10 units of dosimeters were embedded $5 \mathrm{~cm}$ depth on the cave floor while the other 10 units were placed at one meter above ground level by sticking the cups' bottom end to the cave wall. Two (2) dosimeters that were considered as control samples was placed $0.5 \mathrm{~m}$ outside the main entrance. For the purpose of measuring the radon emanation rate, dosimeters which were embedded in the ground were positioned in such a way that the CR-39 sheets were facing down. On the other hand, the dosimeters which were placed $1 \mathrm{~m}$ above ground would provide the data for determining the radon concentration. The wall must be rubbed prior to sticking the dosimeters to get rid of dust that might make it difficult to keep the dosimeters in position through its sampling periods. The radon concentration at 10 locations inside the cave was labeled ascending from L1 to L10 beginning from the entrance of the cave. L0 served as the control sample. Likewise, the dosimeters for radon emanation rate measurement were labeled ascending from L11 to L20 starting from the cave entrance. L00 served as the control sample for emanation rate measurement. The distributions of the dosimeters in the cave are illustrated in Figure 2. The locations of the dosimeters were tagged and visual recorded to avoid losing track of the samples. The samples were then left for 1 month.

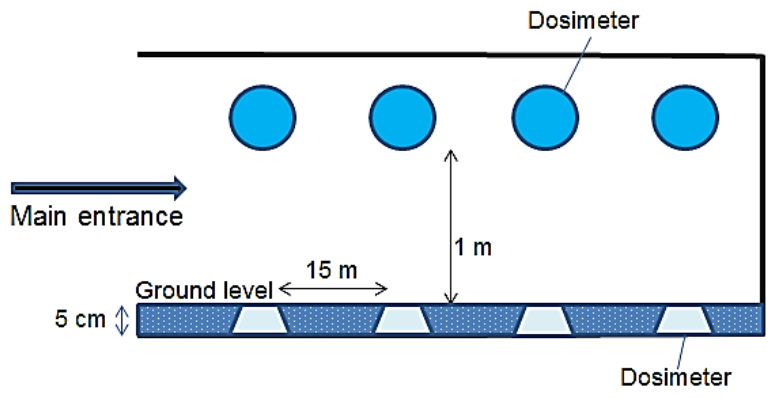

Figure 2. The side view illustration showing distributions of dosimeters inside the cave 


\section{Etching process}

The exposed CR-39 sheet detector were removed from the polymer cup and etched in a $6 \mathrm{M} \mathrm{NaOH}$ at $70{ }^{\circ} \mathrm{C}$ for six hours (constant temperature). During the etching process, the water was stirred once in a while to allow consistent thermal distribution so that the detector would fully etch. Next, the SSNTD sheets were washed in running water for 1 hour and left to dry between tissues wipes for 10 minutes to remove the residual of etchant from the surface of the detector. The track detector sheets were then observed under microscope with magnification of 400x for track density measurements. The tracks would appear as dark spots on a clear white background.

\section{The determination of radon concentration rate}

Radon concentration was calculated according to Equation 1 based on the number of visible spots on the CR-39 sheet. Only dark spots with diameter about $10 \mu \mathrm{m}$ were reckoned for calculation.

$$
\mathrm{C}_{\mathrm{Rn}}=\frac{\mathrm{D}}{\mathrm{Ft}}
$$

where $C_{R n}$ is the radon concentration, $D$ is the track density $\left(\right.$ tracks. $\mathrm{cm}^{-2}$ ), $t$ is the exposure time (days) and $F$ is the calibration factor (tracks $\mathrm{m}^{3} \mathrm{~cm}^{-2} \mathrm{~Bq}^{-1} \mathrm{~h}^{-1}$ ). The radon concentration in air is defined as the number of decays per second per cubic meters of air or $\mathrm{Bqm}^{-3}$.

\section{The determination of annual effective dose}

According to [3], annual effective dose could be calculated using the equation 2.

$$
\mathrm{E}=\mathrm{C} \times \mathrm{H} \times \mathrm{F} \times \mathrm{T} \times \mathrm{D}
$$

where, $\mathrm{C}$ is the radon concentration $\left(\mathrm{Bqm}^{-3}\right), \mathrm{F}$ is the equilibrium factor, $0.4, \mathrm{H}$ is the occupancy factor, $0.8, \mathrm{~T}$ is the number of hours in a year, $8760 \mathrm{~h} \cdot \mathrm{y}^{-1}$ and $\mathrm{D}$ is the effective dose received by adults per unit Radon-222 activities per unit volume, $9.0 \times 10^{-6} \mathrm{mSv} \cdot \mathrm{h}^{-1} \mathrm{Bqm}^{-3}$.

\section{The determination of radon emanation rate}

The Radon-222 emanation rate was calculated using equation 3.

$$
\mathrm{E}_{\mathrm{Rn}}=\frac{\mathrm{CV}}{\mathrm{At}}
$$

where, $\mathrm{E}_{\mathrm{Rn}}$ is the emanation rate $\left(\mathrm{Bqm}^{-2} \mathrm{day}^{-1}\right), \mathrm{C}$ is the Radon-222 concentration $\left(\mathrm{Bqm}^{-3}\right), \mathrm{V}$ is the volume of the polymer container $\left(\mathrm{m}^{3}\right)$, A is the surface area $\left(\mathrm{m}^{2}\right)$ of the lid and $\mathrm{t}$ is the exposure time (days).

\section{Results and Discussion}

Radon emanation rate is defined as the decaying radon atoms that have been released through an area per day. On the other hand, radon concentration is the specific radon activity per unit volume in the atmosphere. The spots on the CR-39 sheets that accounted for concentration measurement were seen as in Figure 3. The dark spot represented the site at which bombardment from the alpha particle that coexists with Radon-222 occurred.

The variation of Radon-222 concentration in Gua Penyu is presented in Figure 4. The average radon concentration was $4.77 \mathrm{~Bq} \mathrm{~m}^{-3}$ with the lowest reading recorded as $3.72 \pm 1.6 \mathrm{Bqm}^{-3}$ at location $\mathrm{L} 2$. There was a noticeable higher readings recorded as of $6.65 \pm 2.1$ and $8.90 \pm 2.1 \mathrm{~Bq} \mathrm{~m}^{-3}$ at locations L6 and L9, respectively. As anticipated, location L9 as the less ventilated compound indicated the highest annual effective dose of $0.20 \mathrm{mSv} \cdot \mathrm{y}^{-1}$ while that of location L2 recorded the lowest, which was $0.09 \mathrm{mSv} \cdot \mathrm{y}^{-1}$. The rest of sampling points gave consistent readings between 3.00 and $5.00 \mathrm{Bqm}^{-3}$. These results indicated that the radon gas was evenly distributed inside the cave. The fact that radon could travel through pores in soil, fractures in rocks and along other weak zone such as shears, faults and thrust [14] might fairly contributed to the occurrence of radon gas movement inside this cave. 


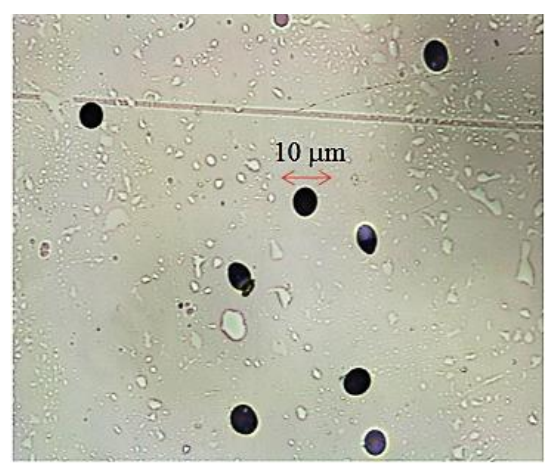

Figure 3. The track photo showing dark spots on the CR-39 sample at location L4

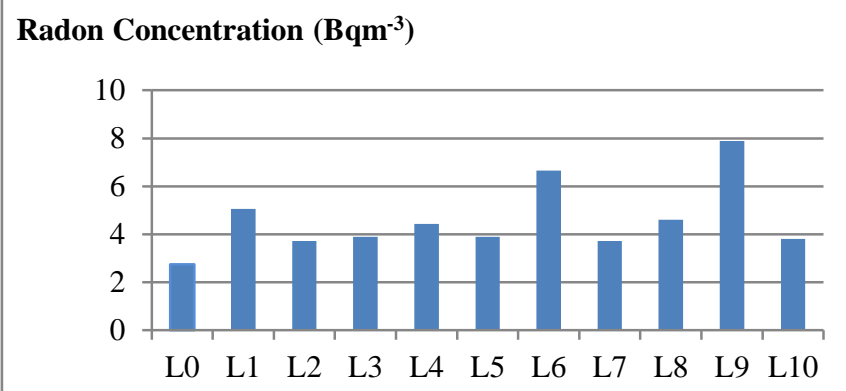

Figure 4. Radon concentrations at sampling locations L0 to L10 at Gua Penyu cave

The irregular high radon concentration at location L1 is unexplainable. Nevertheless, early presumption was that the opening of the cave might be a granitic type of rock which was a greater source of radon. Granite stones emit more radon compared to the other materials because of the existence of relatively high uranium content [15]. Granite samples are also reported as the main source of radon emanations. The effective annual dose of Radon-222 inside Gua Penyu cave is shown in Table 1 . Note that the effective annual dose was derived from the radon concentration. Table 1. The Radon-222 concentration and effective annual dose inside Gua Penyu cave

\begin{tabular}{lcc}
\hline Location & $\begin{array}{c}\text { Radon Concentration } \\
\left(\mathbf{B q m}^{-3}\right)\end{array}$ & $\begin{array}{c}\text { Effective Annual Dose } \\
\left(\mathbf{m S v . \mathbf { y } ^ { - 1 }}\right)\end{array}$ \\
\hline L1 & $5.1 \pm 2.2$ & 0.13 \\
L2 & $3.7 \pm 1.8$ & 0.09 \\
L3 & $3.9 \pm 1.3$ & 0.10 \\
L4 & $4.4 \pm 1.5$ & 0.11 \\
L5 & $3.9 \pm 1.2$ & 0.10 \\
L6 & $6.7 \pm 2.1$ & 0.17 \\
L7 & $3.7 \pm 1.6$ & 0.09 \\
L8 & $4.6 \pm 1.8$ & 0.12 \\
L9 & $7.9 \pm 2.1$ & 0.20 \\
L10 & $3.8 \pm 1.3$ & 0.10 \\
Average & $4.8 \pm 0.6$ & 0.12 \\
\hline
\end{tabular}


Figure 5 shows the etched radon alpha track on sample at location L13. The sample was left for a period of one month for determination of radon emanation rate in Gua Penyu. The higher number of spots than in Figure 3 was a result of it being embedded closer to ground as the major source for Radon-222 after it decayed from Radium-226.

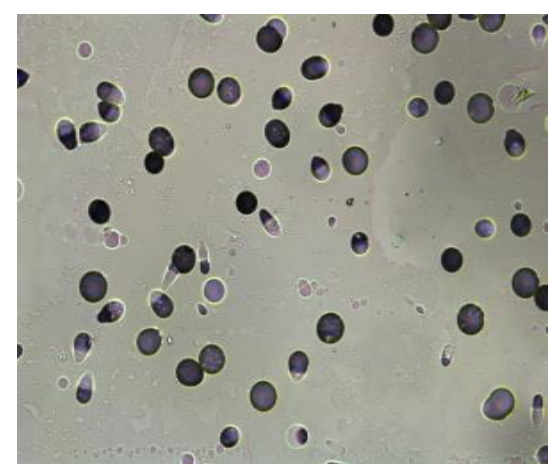

Figure 5. The track showing dark spots on the CR-39 sample at location L13

Radon-222 emanation rate of all study locations were presented in Figure 6. The radon emanation rate for the whole locations ranged between $0.030 \pm 0.004 \mathrm{Bqm}^{-2} \mathrm{day}^{-1}$ and $0.120 \pm 0.017 \mathrm{Bqm}^{-2} \mathrm{day}^{-1}$ with the average rate was 0.080 $\mathrm{Bqm}^{-2} \mathrm{day}^{-1}$.

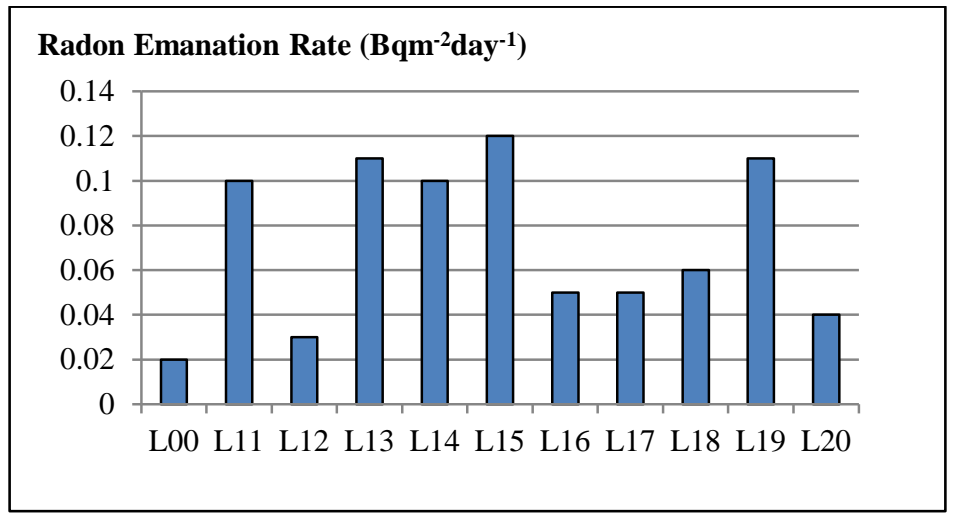

Figure 6. Radon emanation rates at sampling locations L00 to L20 at Gua Penyu cave

The variation in radon emanation rates according to locations indicated different amount of Uranium-238 that exist at sampling locations. This was expected as uranium concentration depends very much on the types of soil and rock. Figure 7 indicates the correlation between the indoor Radon-222 emanation rates and concentrations at sampling location beginning from the main entrance of the cave. This result infers the influence of radon emanation rate to its concentration in poor ventilated vicinity. It shows that higher emanation rates produced higher concentration of radon over time. More importantly, higher rate of emanation means higher level of uranium concentration in the cave ground [16]. As a result, more radon gas was emitted leading to the accumulation of this gas inside the cave. On the contrary, there was a dissimilar trend at sampling locations towards the center of the cave which could be attributed to the mixture and dilution of radon gas near the entrance whereas a consequence of none air ventilation towards the closed end. This was possible since radon gas emission depends on distribution of rocks underneath the cave floor as a major source of this gas. 


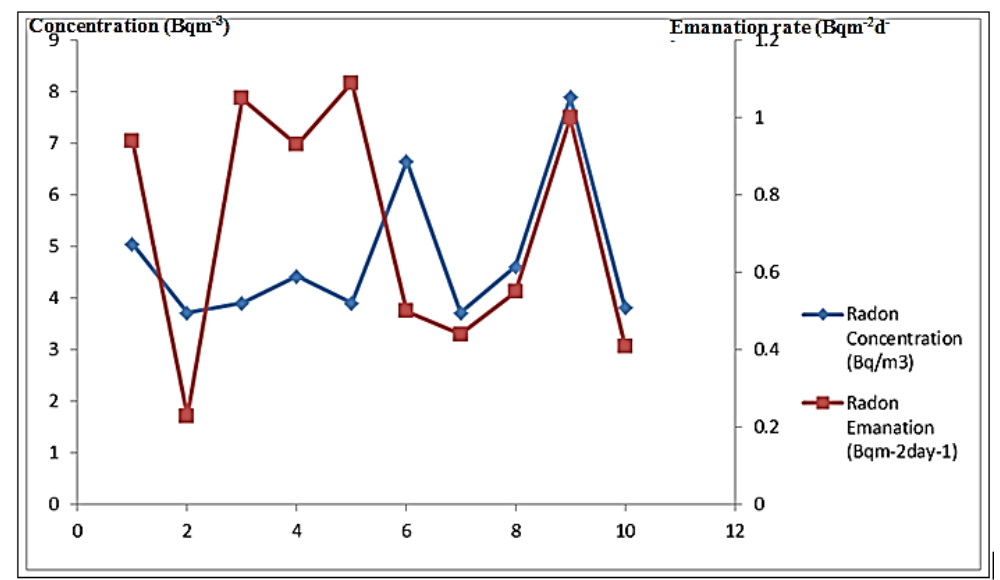

Figure 7. The relation between concentrations and emanation rates of Radon-222 according to sampling locations inside Gua Penyu cave

In this study, the Radon-222 concentration rates were found ranging from $3.7 \pm 1.6 \mathrm{Bqm}^{-3}$ to $7.9 \pm 2.1 \mathrm{Bqm}^{-3}$. The average radon concentration was $4.77 \mathrm{Bqm}^{-3}$. This value was lower compared to other local places such as Puchong $\left(6.6 \mathrm{Bqm}^{-3}\right)$ and Johor Bharu $\left(5.0 \mathrm{Bqm}^{-3}\right)$ as reported by Saat and Hamzah [3]. Note that, as far as the quality of air was concerned, the value was much lower than the indoor concentration allowed by The International Commission on Radiation Protection 2009 [17]. The radon emanation rate on the other hand, ranged from $0.030 \pm 0.004 \mathrm{Bqm}^{-}$ ${ }^{2} \mathrm{day}^{-1}$ to $0.120 \pm 0.017 \mathrm{~Bq}^{-2} \mathrm{day}^{-1}$ with an average of $0.08 \mathrm{Bqm}^{-2} \mathrm{day}^{-1}$. The effective annual dose ranged between $0.09 \mathrm{mSv} \cdot \mathrm{y}^{-1}$ and $0.20 \mathrm{mSv} \cdot \mathrm{y}^{-1}$, remained harmless if compared to the recommended effective annual dose by ICRP 1993 which was 3-10 mSv. ${ }^{-1}$.

\section{Conclusion}

The International Commission on Radiation Protection (ICRP) has recommended that remedial action against radon and its progeny is justified above a continued effective dose of 3 to $10 \mathrm{mSv} \cdot \mathrm{y}^{-1}$ [18]. The action level for radon activity should be in the range of 200-300 $\mathrm{Bqm}^{-3}$ [17]. The indoor Radon-222 concentrations, emanation rates and effective annual dose in Gua Penyu cave were all below the recommended ICRP action levels. In conclusion, Gua Penyu cave was harmless to be visited by holidaymakers.

\section{Acknowledgement}

The authors would like to sincerely thank the management of Tekam Plantation Resorts (Cave Division), Malaysia for helping and supporting this study and the Institute of Science, Universiti Teknologi MARA for allowing this work to be completed in their facility.

\section{References}

1. Elzaher, M. A. (2012). An overview on studying ${ }^{222} \mathrm{Rn}$ exhalation rates using passive technique solid-state nuclear track detectors. American Journal of Applied Sciences, 9 (10): 1653-1659.

2. Rowan, E. L., and Kraemer, T. F. (2012). Radon-222 content of natural gas samples from upper and middle Devonian sandstone and shale reservoirs in Pennsylvania: Preliminary data. U.S. Geological Survey Open-File Report 2012-1159: pp. 6.

3. Saat, A. and Hamzah, Z. (2012). Indoor and outdoor Radon-222 concentration at various locations in Peninsular Malaysia. Proceedings-INTEC Academic Conference, 2012: 48-54.

4. Sharma, J., Mahur, A. K., Kumar, R., Varshney, R, Sonkawade, R. G, Swarup, R., Singh, H. and Prasad, R. (2012). Comparative study of indoor radon, thoron with radon exhalation rate in soil samples in some historical places at Jaipur, Rajasthan, India. Advances in Applied Science Research, 3(2):1085-1091.

5. Najam, L. A, Tawfiq, N. F. and Mahmood, R. H. (2013). Radon concentration in some building in Iraq using CR-39 track detector. International Journal of Physics, 1(3): 73-76. 
6. International Atomic Energy Agency (2003). Radiation protection against radon in workplaces other than mines. Safety reports series no. 33, IAEA, Vienna.

7. Yu, K. N., Nikezic, D., Ng, F. M. F. and Leung, J. K. C. (2005). Long-term measurements of radon progeny concentrations with solid-state nuclear track detectors. Journal of Radiation Measurements, 40: 560-568.

8. World Health Organization (2009). WHO handbook on indoor radon: A public health perspective. Avenue Appia, 1211 Geneva, Switzerland.

9. Oufni, L., Misdaq, M. A. and Amrane, A. (2005). Radon level and radon effective dose rate determination in Moroccan dwellings using SSNTDs. Journal of Radiation Measurements, 40: 118-123.

10. Koltai, G., Tegzes, Z. and Hulber, E. (2014). First results of the radon concentration monitoring in Abaliget and Kispaplika Caves. Acta Climatologica et Chorologica, 47-48: 71-76.

11. Ahn, G. H. and Lee, J. K. (2005). Construction of an environmental radon monitoring system using CR-39 nuclear track detectors. Nuclear Engineering and Technology, 37(4):395-400.

12. Maghrabi, A. M., Alzimami, K. and Abo-Elmagd, M. (2014). Estimation of the residential radon levels and the population annual effective dose in dwellings of Al-Kharj, Saudi Arabia. Journal of Radiation Research and Applied Sciences, 7: 577-582.

13. Sainz, C., Dinu, A., Dicu, T., Szacsvai, K., Cosma, C. and Quindos, L.S. (2009). Comparative risk assessment of residential radon exposures in two radon-prone areas, Stei (Romania) and Torrelodones (Spain). Science of the Total Environment, 407(15):4452-4460.

14. Mansour, H. L., Tawfiq, N. F., and Karim, M. S. (2014). Indoor radon concentrations measurement in the dwellings of Thi-Qar governorate, Iraqi. Journal of Natural Sciences, 2(1):19-26.

15. Nassiri, P., Ebrahimi, H. and Shalkouhi, J. P. (2011). Evaluation of radon exhalation rate from granite stone. Journal of Scientific \& Industrial Research, 70: 230-231.

16. Bohus, L. S, Greaves, E. D, Palfalvi, J, Urbani, F. and Merlo, G. (1997). Radon concentration measurements in Venezuelan caves using SSNTDS. Journal of Radiation Measurement, 28(1-6): 725-728.

17. International Commission on Radiological Protection (2009), Statement on Radon. Ref00/902/09, 23(2): 1-44.

18. International Commission on Radiological Protection (1993). Protection against Radon-222 at home and at work, ICRP Publication, 23(2). 